\title{
A Stable Pillared-layer Metal-organic Framework for Recovery of C2H6 and C3H8 from Natural Gas
}

\author{
Yufang $\mathrm{Wu}^{1}$, Zewei $\mathrm{Liu}^{1}$, Xun Wang ${ }^{1}$, and Zhong $\mathrm{Li}^{1}$ \\ ${ }^{1}$ South China University of Technology
}

May 29, 2020

\begin{abstract}
Separation and recovery of $\mathrm{C} 2 \mathrm{H} 6$ and $\mathrm{C} 3 \mathrm{H} 8$ from natural gas is a potentially economical but challenging subject in the petroleum industry. In this work, we report a stable pillared-layer microporous MOF, Ni(TMBDC)(DABCO)0.5 for the separation of $\mathrm{C} 2 \mathrm{H} 6$ and $\mathrm{C} 3 \mathrm{H} 8$ from natural gas. $\mathrm{Ni}(\mathrm{TMBDC})(\mathrm{DABCO}) 0.5$ remained intact structure after exposure to humid air with $\mathrm{RH}=100 \%$ for days. Derived from the combination of dense and accessible methyl group and methylene group in the channel, Ni(TMBDC)(DABCO)0.5 exhibited strong affinity toward C3H8 and C2H6, with remarkably high capacities of 2.80 $\mathrm{mmol} / \mathrm{g}$ at $1 \mathrm{kPa}$ and $3.37 \mathrm{mmol} / \mathrm{g}$ at $5 \mathrm{kPa}$ for $\mathrm{C} 3 \mathrm{H} 8$, as well as $2.93 \mathrm{mmol} / \mathrm{g}$ at $10 \mathrm{kPa}$ for C2H6. Its IAST selectivities of $\mathrm{C} 3 \mathrm{H} 8 / \mathrm{CH} 4$ and $\mathrm{C} 2 \mathrm{H} 6 / \mathrm{CH} 4$ reached 274 and 29, respectively. The complete separation of $\mathrm{CH} 4 / \mathrm{C} 2 \mathrm{H} 6 / \mathrm{C} 3 \mathrm{H} 8$ ternary mixture on breakthrough experiment demonstrated the great potential on recovery of $\mathrm{C} 2 \mathrm{H} 6$ and $\mathrm{C} 3 \mathrm{H} 8$ from natural gas through a $\mathrm{Ni}(\mathrm{TMBDC})(\mathrm{DABCO}) 0.5$ packed column.
\end{abstract}

\section{A Stable Pillared-layer Metal-organic Framework for Recovery of $\mathrm{C}_{2} \mathrm{H}_{6}$ and $\mathrm{C}_{3} \mathrm{H}_{8}$ from Natural Gas \\ Yufang Wu, ${ }^{\text {a }}$ Zewei Liu, ${ }^{\text {a }}$ Xun Wang, ${ }^{\text {a a }}$ Zhong Li, ${ }^{\text {a }, \mathrm{b}}$ \\ ${ }^{a}$ School of Chemistry and Chemical Engineering, South China University of Technology, Guangzhou, 510640, China; E-mail: cezhli@scut.edu.cn \\ ${ }^{b}$ State Key Lab of Subtropical Building Science of China, South China University of Technology, Guangzhou 510640, PR China}

Abstract: Separation and recovery of $\mathrm{C}_{2} \mathrm{H}_{6}$ and $\mathrm{C}_{3} \mathrm{H}_{8}$ from natural gas is a potentially economical but challenging subject in the petroleum industry. In this work, we report a stable pillared-layer microporous MOF, $\mathrm{Ni}(\mathrm{TMBDC})(\mathrm{DABCO})_{0.5}$ for the separation of $\mathrm{C}_{2} \mathrm{H}_{6}$ and $\mathrm{C}_{3} \mathrm{H}_{8}$ from natural gas. $\mathrm{Ni}(\mathrm{TMBDC})(\mathrm{DABCO})_{0.5}$ remained intact structure after exposure to humid air with $\mathrm{RH}=100 \%$ for days. Derived from the combination of dense and accessible methyl group and methylene group in the channel, $\mathrm{Ni}(\mathrm{TMBDC})(\mathrm{DABCO})_{0.5}$ exhibited strong affinity toward $\mathrm{C}_{3} \mathrm{H}_{8}$ and $\mathrm{C}_{2} \mathrm{H}_{6}$, with remarkably high capacities of $2.80 \mathrm{mmol} / \mathrm{g}$ at 1 $\mathrm{kPa}$ and $3.37 \mathrm{mmol} / \mathrm{g}$ at $5 \mathrm{kPa}$ for $\mathrm{C}_{3} \mathrm{H}_{8}$, as well as $2.93 \mathrm{mmol} / \mathrm{g}$ at $10 \mathrm{kPa}$ for $\mathrm{C}_{2} \mathrm{H}_{6}$. Its IAST selectivities of $\mathrm{C}_{3} \mathrm{H}_{8} / \mathrm{CH}_{4}$ and $\mathrm{C}_{2} \mathrm{H}_{6} / \mathrm{CH}_{4}$ reached 274 and 29 , respectively. The complete separation of $\mathrm{CH}_{4} / \mathrm{C}_{2} \mathrm{H}_{6} / \mathrm{C}_{3} \mathrm{H}_{8}$ ternary mixture on breakthrough experiment demonstrated the great potential on recovery of $\mathrm{C}_{2} \mathrm{H}_{6}$ and $\mathrm{C}_{3} \mathrm{H}_{8}$ from natural gas through a $\mathrm{Ni}(\mathrm{TMBDC})(\mathrm{DABCO})_{0.5}$ packed column.

Key words: Metal-organic framework, light hydrocarbons, natural gas, separation, stability

\section{Introduction}

Natural gas (NG), as a promising clean energy, has been widely used with an increasing trend in recent years. $^{[1]}$ Natural gas consists primarily of methane, including location-dependent ratio of $12 \sim 39 \%$ of other 
heavier light hydrocarbons, such as ethane, propane, n-butane, etc. ${ }^{[2,3]}$ Among these light hydrocarbons, $\mathrm{C}_{2} \mathrm{H}_{6}$ and $\mathrm{C}_{3} \mathrm{H}_{8}$ are of great value in the petrochemical industry. $\mathrm{C}_{2} \mathrm{H}_{6}$ is the most important raw material for the ethylene production which serves as the main component of the polyethylene, polyvinyl chloride and other polymer. $\mathrm{C}_{3} \mathrm{H}_{6}$ is also the basic feedstock for the propylene and polypropylene production. ${ }^{[3,4]}$ Direct combustion of $\mathrm{NG}$ for heat supply without recovery of $\mathrm{C}_{2} \mathrm{H}_{6}$ and $\mathrm{C}_{2} \mathrm{H}_{8}$ would cause an enormous waste of these ethane (C2) and propane (C3) resources. Therefore, in order to fully utilize these hydrocarbons, it is essential to recover the ethane $(\mathrm{C} 2)$ and propane (C3) from the natural gas for the high-purity alkene production. Although the cryogenic distillation, which is based on the small differences in boiling point of each component, may be used for the separation of $\mathrm{C} 1 / \mathrm{C} 2 / \mathrm{C} 3$, it is an energy-intensive separation technology. ${ }^{[3,5]}$ Adsorptive separation is considered as one of the most promising techniques because of its low energy consumption and high separation efficiency. ${ }^{[1,6,7]}$

In adsorption technology, the adsorbent with excellent separation properties is the core. ${ }^{[7]}$ Therefore, considerable efforts have been made to develop porous materials with high adsorption capacity and selectivity for separation of $\mathrm{C} 1 / \mathrm{C} 2 / \mathrm{C} 3$. Traditional porous materials, such as zeolites, carbonaceous materials, are employed to separate the $\mathrm{C} 1 / \mathrm{C} 2 / \mathrm{C} 3$ mixtures but most of them exhibited either low capacity or low selectivity for these hydrocarbons. ${ }^{[8,9]}$ In recent years, metal-organic frameworks (MOFs), comprised of metal ions/clusters and organic linkers, has emerged and the diversity of the organic/inorganic linkers and exquisite control over pore aperture size promise MOFs great potential in the areas of gas storage ${ }^{[10]}$ catalysis, ${ }^{[11,12]}$ sensing, ${ }^{[13,14]}$ gas separations. ${ }^{[16-27]}$

Since the concentrations of ethane and propane are about $5 \%$ and $10 \%$ in natural gas respectively, ${ }^{[2]}$ a MOF material with high gas capacity under low pressure area $(5 \mathrm{kPa} \sim 10 \mathrm{kPa})$ is highly demanded to address the issue of separation of $\mathrm{C} 1 / \mathrm{C} 2 / \mathrm{C} 3$. As a benchmark material for hydrocarbon separations, MOF-74(Co) was reported to adsorb $3 \mathrm{mmol} / \mathrm{g}$ propane at $5 \mathrm{kPa}$ and $3.1 \mathrm{mmol} / \mathrm{g}$ ethane at $10 \mathrm{kPa}$, while it was humid unstable. ${ }^{[28,29]}$ In addition, the Gly@HKUST-1 exhibited $4.22 \mathrm{mmol} / \mathrm{g}$ propane at $5 \mathrm{kPa}$ and $1.19 \mathrm{mmol} / \mathrm{g}$ ethane at $10 \mathrm{kPa} \cdot{ }^{[26]}$ However, most of other MOFs reported for separation of $\mathrm{C} 1 / \mathrm{C} 2 / \mathrm{C} 3$ exhibited low adsorption capacity at low pressure region. ${ }^{[26-27,36-38]}$ In order to improve the $\mathrm{C} 2 / \mathrm{C} 3$ low-pressure adsorption ability, a microporous MOF material with pore size slightly larger than molecule sizes of propane and ethane is required, which may lead to the enhancement of the interaction between framework and propane/ethane molecule. A pillared-layer MOF, $\mathrm{Ni}(\mathrm{TMBDC})(\mathrm{DABCO})_{0.5}{ }^{[30]}$, was found to show strong affinity towards $\mathrm{C}_{2} \mathrm{H}_{6}$ at low pressure area. In the structure of this material, the $2 \mathrm{D}$-layer is connected by nickel paddle-wheels and 2,3,5,6-tetramethylterephthalic acid (TMBDC) and bridged by 1,4-Diazabicyclo[2.2.2]octane (DABCO) to produce a $3 \mathrm{D}$ network with the topology of pcu . The pore size of $\mathrm{Ni}(\mathrm{TMBDC})(\mathrm{DABCO})_{0.5}$ is 0.59 $\mathrm{nm}$, which is slightly larger than molecular sizes of propane $(0.50 \mathrm{~nm})$ and ethane $(0.44 \mathrm{~nm})$. Therefore, $\mathrm{Ni}(\mathrm{TMBDC})(\mathrm{DABCO})_{0.5}$ would be a promising MOF material for the separation of $\mathrm{C} 1 / \mathrm{C} 2 / \mathrm{C} 3$.

Herein, we reported the synthesis of $\mathrm{Ni}(\mathrm{TMBDC})(\mathrm{DABCO})_{0.5}$ and its performance of separating light hydrocarbons for the recovery of $\mathrm{C}_{3} \mathrm{H}_{8}$ and $\mathrm{C}_{2} \mathrm{H}_{6}$ from natural gas. The stability of the material was estimated by TG analysis and PXRD characterization. The $\mathrm{CH}_{4}, \mathrm{C}_{2} \mathrm{H}_{6}$ and $\mathrm{C}_{3} \mathrm{H}_{8}$ adsorption isotherms on $\mathrm{Ni}(\mathrm{TMBDC})(\mathrm{DABCO})_{0.5}$ were measured and the separation performance of $\mathrm{C} 1 / \mathrm{C} 2 / \mathrm{C} 3$ ternary mixture was further evaluated by breakthrough experiment. The selectivity of $\mathrm{C}_{2} \mathrm{H}_{6} / \mathrm{CH}_{4}$ and $\mathrm{C}_{3} \mathrm{H}_{8} / \mathrm{CH}_{4}$ were predicted by ideal adsorbed solution theory (IAST) model. In addition, molecule simulation was applied to investigate the adsorption mechanism of these light hydrocarbons in the pores of $\mathrm{Ni}(\mathrm{TMBDC})(\mathrm{DABCO})_{0.5}$.

\section{Experimental}

Materials

All chemical reagents were purchased from commercial sources (J\&K Chemical, Aladdin, Macklin, et.al.) and used without further purifications. 2,3,5,6-Tetramethylterephthalic acid (TMBDC) was synthesized based on a reported procedure in the literature. ${ }^{[30,31]}$

Synthesis of $\mathrm{Ni}(\mathrm{TMBDC})(\mathrm{DABCO})_{0.5}$ 
The $\mathrm{Ni}(\mathrm{TMBDC})(\mathrm{DABCO})_{0.5}$ was synthesized according to the reported procedure ${ }^{[30]}$. Typically, in a 20 $\mathrm{mL}$ vial, $\mathrm{Ni}\left(\mathrm{NO}_{3}\right)_{2} \cdot 6 \mathrm{H}_{2} \mathrm{O}(0.093 \mathrm{~g}, 0.32 \mathrm{mmol})$, DABCO $(0.018 \mathrm{~g}, 0.16 \mathrm{mmol})$, TMBDC $(0.067 \mathrm{~g}, 0.03 \mathrm{mmol})$ were mixed in $8 \mathrm{~mL}$ DMF and then 1 drop of $\mathrm{HNO}_{3}$ was added, followed by sonication for $5 \mathrm{~min}$. The resulting green solution was heated at 120 for $48 \mathrm{~h}$ to afford the green crystals. The crystals were collected by filtration and washed in DMF to remove the excess reactants and then soaked into ethanol for 2 days. The obtained $\mathrm{Ni}(\mathrm{TMBDC})(\mathrm{DABCO})_{0.5}$ was kept in ethanol before further experiments.

\section{Characterizations}

The $\mathrm{N}_{2}$ adsorption-desorption isotherms were measured on Micrometrics ASAP 2460 at $77 \mathrm{~K}$ using a liquid $\mathrm{N}_{2}$ bath. The BET surface area was calculated using the Brunauer-Emmett-Teller equation in the range $\mathrm{P} / \mathrm{P}_{0}=0.05-0.35$ and the pore size distribution was calculated by DFT method based on the $\mathrm{N}_{2}$ adsorption amount at the pressure of $\mathrm{P} / \mathrm{P}_{0}=0.95$. The sample was filtered using a Buchner funnel and degassed at 120 for $6 \mathrm{~h}$ before each analysis.

Powder X-ray diffraction (PXRD) was performed on the Bruker AXS D8 Advance using Cu K $\alpha(\lambda=1.5406 \AA)$ radiation at $5^{\circ}-40^{\circ}$. TGA curve was measured on NETZSCH STA 449F3 Simultaneous Thermal Analyzer (NETZSCH, Germany) at temperature range of $30{ }^{\circ} \mathrm{C}$ to $700{ }^{\circ} \mathrm{C}$ with $10{ }^{\circ} \mathrm{C} /$ min heating rate under $\mathrm{N}_{2}$ atmosphere.

Adsorption isotherms measurement

The single component adsorption isotherms of $\mathrm{CH}_{4}, \mathrm{C}_{2} \mathrm{H}_{6}$ and $\mathrm{C}_{3} \mathrm{H}_{8}$ were collected on 3Flex Surface Characterization Analyzer (Micromeritics, USA) at $288 \mathrm{~K}, 298 \mathrm{~K}$ and $308 \mathrm{~K}$. Prior to each measurement, the ethanol-soaked sample was filtered and then degassed at 120 under vacuum for $6 \mathrm{~h}$.

Stability test

To investigate the stability of $\mathrm{Ni}(\mathrm{TMBDC})(\mathrm{DABCO})_{0.5}$ in varied solution or under humidity conditions, the ethanol soaked sample was filtered and dried in the air firstly and then immersed into varied solution (acetone, hexane, dichloromethane) or exposed to humid air with $\mathrm{RH}=100 \%$ and $\mathrm{RH}=55 \%$, respectively. After 4 days, the samples were collected by filtration and characterized by PXRD technique.

Breakthrough experiments

The breakthrough curves of gas mixture $\mathrm{CH}_{4} / \mathrm{C}_{2} \mathrm{H}_{6} / \mathrm{C}_{3} \mathrm{H}_{8}(85: 10: 5, \mathrm{v} / \mathrm{v} / \mathrm{v})$ were measured on a self-assembly experimental apparatus (ESI). The carrier gas was $\mathrm{N}_{2}$ with flow rate of $45 \mathrm{~mL} / \mathrm{min}$ and the flow rate of $\mathrm{CH}_{4} / \mathrm{C}_{2} \mathrm{H}_{6} / \mathrm{C}_{3} \mathrm{H}_{8}$ mixture gas was controlled at $5 \mathrm{~mL} / \mathrm{min}$ by a mass flow controller (FMA-A200, America). The composition of exit gas stream from the adsorption column was determined on-line on a gas chromatography apparatus (GC-9560, Shanghai Huaai), equipped with a $2 \mathrm{~m}$ long $\mathrm{Al}_{2} \mathrm{O}_{3}$-packed column with an FID detector. Typically, about $300 \mathrm{mg}$ dry sample was packed into a stainless steel column with inner dimension of $\Phi 3 \times 275 \mathrm{~mm}$. The six-way valve was used to collect and send the sample gas with constant amount into the GC automatically every 90 seconds. For the cycling tests, the sample packed column was regenerated by purging $\mathrm{N}_{2}$ flow $(30 \mathrm{~mL} / \mathrm{min})$ at $100{ }^{\circ} \mathrm{C}$ for $30 \mathrm{~min}$. After that the gas flow was switched to $\mathrm{CH}_{4} / \mathrm{C}_{2} \mathrm{H}_{6} / \mathrm{C}_{3} \mathrm{H}_{8}$ mixture for the next cycle.

Simulation details

Adsorption properties of pure $\mathrm{CH}_{4}, \mathrm{C}_{2} \mathrm{H}_{6}$ and $\mathrm{C}_{3} \mathrm{H}_{8}$ on $\mathrm{Ni}(\mathrm{TMBDC})(\mathrm{DABCO})_{0.5}$ were simulated by Grand Canonical Monte Carlo (GCMC) method. All GCMC simulations were carried out by the Sorption modules in Materials Studio (Version 2017 R2). In this study, the universal force field (UFF) was adopted. The Ewald summation method was used to calculate the electrostatic energy and the atom based method was applied to describe the van der Waals interaction.

\section{Results and discussion}

Characterization of samples 
(a)

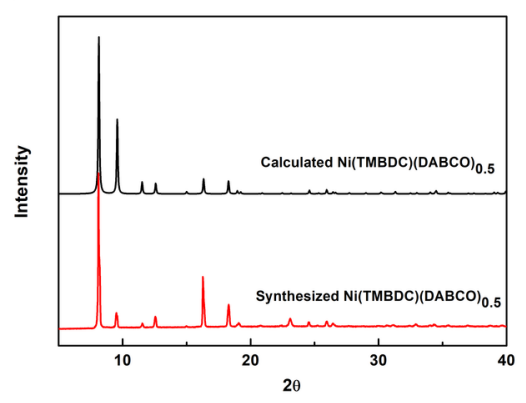

(b)

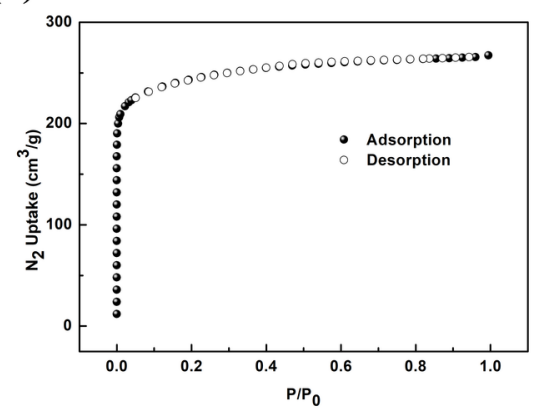

Figure 1 (a) PXRD patterns of fresh and calculated Ni(TMBDC)(DABCO) $0_{0.5}$; (b) $\mathrm{N}_{2}$ adsorption-desorption isotherms of $\mathrm{Ni}(\mathrm{TMBDC})(\mathrm{DABCO})_{0.5}$ at $77 \mathrm{~K}$

Figure 1(a) presents the comparison between the calculated and experimental PXRD patterns of the sample $\mathrm{Ni}(\mathrm{TMBDC})(\mathrm{DABCO})_{0.5}$. It can be observed that the PXRD pattern of the synthesized $\mathrm{Ni}(\mathrm{TMBDC})(\mathrm{DABCO})_{0.5}$ shows two obvious characteristic peaks at $8.1^{\circ}$ and $9.5^{\circ}$, which are in good agreement with the calculated PXRD pattern, suggesting the successful synthesis of the $\mathrm{Ni}(\mathrm{TMBDC})(\mathrm{DABCO})_{0.5}$.

To assess the permanent porosity of the $\mathrm{Ni}(\mathrm{TMBDC})(\mathrm{DABCO})_{0.5}, \mathrm{~N}_{2}$ adsorption-desorption isotherms were measured at $77 \mathrm{~K}$. As shown in Figure 1(b), the $\mathrm{N}_{2}$ adsorption-desorption isotherms of $\mathrm{Ni}(\mathrm{TMBDC})(\mathrm{DABCO})_{0.5}$ exhibits a characteristic type-I isotherm with steeply increasing $\mathrm{N}_{2}$ adsorption capacity at relatively low pressures and a maximum $N_{2}$ uptake of $267 \mathrm{~cm}^{3} / \mathrm{g}$ at $P / P_{0}=1$ was achieved, indicating its microporosity. Derived from the $\mathrm{N}_{2}$ isotherms, the BET surface area and total pore volume of $\mathrm{Ni}(\mathrm{TMBDC})(\mathrm{DABCO})_{0.5}$ are $940 \mathrm{~m}^{2} / \mathrm{g}$ and $0.41 \mathrm{~cm}^{3} / \mathrm{g}$, respectively. The pore size of $\mathrm{Ni}(\mathrm{TMBDC})(\mathrm{DABCO})_{0.5}$ is uniformly $0.5 \mathrm{~nm}$, as shown in Figure $\mathrm{S} 2$, which is amenable to kinetic diameters of $\mathrm{C}_{3} \mathrm{H}_{8}$ and $\mathrm{C}_{2} \mathrm{H}_{6}$, implying the great potential on separation of $\mathrm{C} 3 / \mathrm{C} 2 / \mathrm{C} 1$ mixture.

(a)

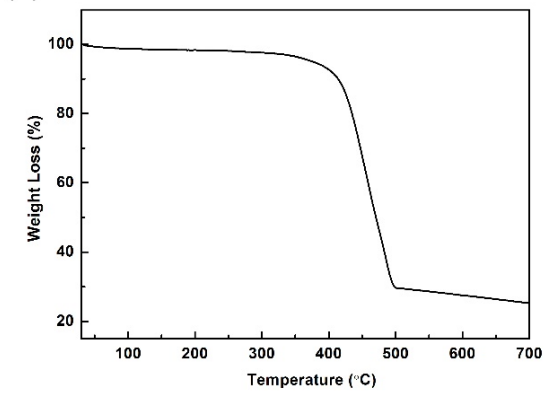

(b)

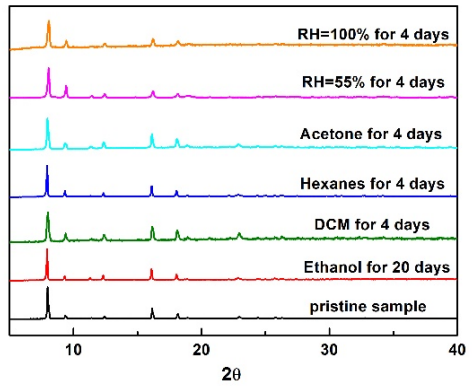

Figure 2 (a) TGA curve of $\mathrm{Ni}(\mathrm{TMBDC})(\mathrm{DABCO})_{0.5}$; (b) PXRD patterns of $\mathrm{Ni}(\mathrm{TMBDC})(\mathrm{DABCO})_{0.5}$ before and after various treatment.

TGA data were collected for the evaluation of the thermal stability of the Ni(TMBDC)(DABCO $)_{0.5}$. Figure 2(a) presents the TGA curve of $\mathrm{Ni}(\mathrm{TMBDC})(\mathrm{DABCO})_{0.5}$. It is noticed that the TGA curve showed a negligible weight loss $(\sim 5 \%)$ before $400{ }^{\circ} \mathrm{C}$ which was attributed to the removal of guest molecules such as $\mathrm{H}_{2} \mathrm{O}$ molecule. After $400{ }^{\circ} \mathrm{C}$, a great weight loss $\left({ }^{\sim} 68 \%\right)$ occurred due to the decomposition of the framework structure. It suggests that the $\mathrm{Ni}(\mathrm{TMBDC})(\mathrm{DABCO})_{0.5}$ is thermally stable until $400{ }^{\circ} \mathrm{C}$.

We also examined the solvent stability and water vapor stability of the $\mathrm{Ni}(\mathrm{TMBDC})(\mathrm{DABCO})_{0.5}$. Figure 2(b) shows the PXRD patterns of $\mathrm{Ni}(\mathrm{TMBDC})(\mathrm{DABCO})_{0.5}$ before and after soaking in various solvents or 
exposure to humid air for several days. It is visible that the $\mathrm{Ni}(\mathrm{TMBDC})(\mathrm{DABCO})_{0.5}$ retained the structural integrity after soaking separately in acetone, DCM, Hexanes for 4 days and ethanol for 20 days, demonstrating excellent stability in these organic solvents. Furthermore, the water vapor stability was tested by exposing the $\mathrm{Ni}(\mathrm{TMBDC})(\mathrm{DABCO})_{0.5}$ to humid air with $55 \%$ and $100 \%$ humidity for 4 days. The PXRD patterns of $\mathrm{Ni}(\mathrm{TMBDC})(\mathrm{DABCO})_{0.5}$ after exposure to humid air are similar to that of the fresh material, suggesting its excellent humid stability. The water vapor stability could be attributed to the hydrophobicity of the channel of $\mathrm{Ni}(\mathrm{TMBDC})(\mathrm{DABCO})_{0.5}$, which is caused by the methyl group on the TMBDC ligand and the methylene group on the DABCO ligand.

$\mathrm{CH}_{4}, \mathrm{C}_{2} \mathrm{H}_{6}$ and $\mathrm{C}_{3} \mathrm{H}_{8}$ isotherms and $\mathrm{C}_{2} \mathrm{H}_{6} / \mathrm{CH}_{4}, \mathrm{C}_{3} \mathrm{H}_{8} / \mathrm{CH}_{4}$ selectivity of the sample

(a)

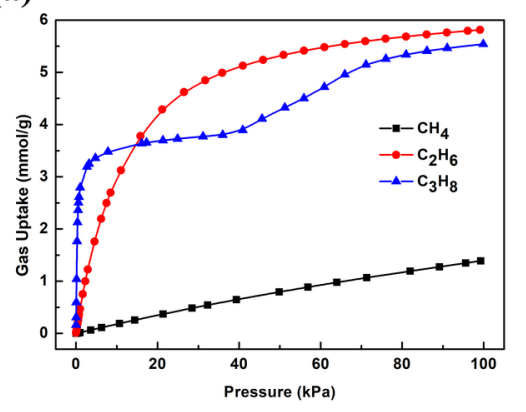

(b)

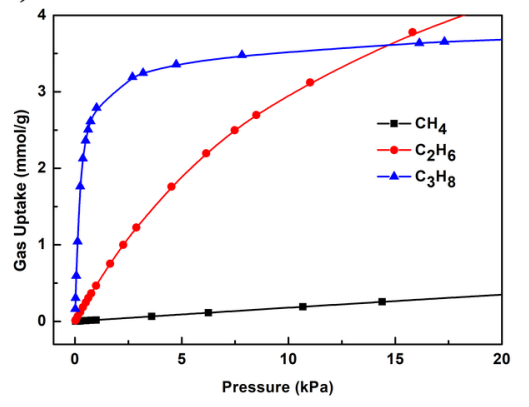

Figure $3 \mathrm{CH}_{4}, \mathrm{C}_{2} \mathrm{H}_{6}$ and $\mathrm{C}_{3} \mathrm{H}_{8}$ adsorption isotherms of $\mathrm{Ni}(\mathrm{TMBDC})(\mathrm{DABCO})_{0.5}$ at $298 \mathrm{~K}$ in the pressure region of (a) $0 \sim 100 \mathrm{kPa}$ and (b) $0 \sim 20 \mathrm{kPa}$

Figure 3 presents the $\mathrm{CH}_{4}, \mathrm{C}_{2} \mathrm{H}_{6}$ and $\mathrm{C}_{3} \mathrm{H}_{8}$ adsorption isotherms of $\mathrm{Ni}(\mathrm{TMBDC})(\mathrm{DABCO})_{0.5}$ at $298 \mathrm{~K}$. The $\mathrm{C}_{3} \mathrm{H}_{8}$ and $\mathrm{C}_{2} \mathrm{H}_{6}$ uptakes on $\mathrm{Ni}(\mathrm{TMBDC})(\mathrm{DABCO})_{0.5}$ are much higher than $\mathrm{CH}_{4}$, reaching as high as 5.54 $\mathrm{mmol} / \mathrm{g}$ and $5.81 \mathrm{mmol} / \mathrm{g}$ at $100 \mathrm{kPa}$, respectively. As shown in Figure 3(b), at low pressure region of $0 \sim 15$ $\mathrm{kPa}$, the $\mathrm{C}_{3} \mathrm{H}_{8}$ isotherm exhibits a steeply increasing trend in $\mathrm{C}_{3} \mathrm{H}_{8}$ adsorption capacity and the uptake of each gas in $\mathrm{Ni}(\mathrm{TMBDC})(\mathrm{DABCO})_{0.5}$ decreased in the order of $\mathrm{C}_{3} \mathrm{H}_{8}>\mathrm{C}_{2} \mathrm{H}_{6}>\mathrm{CH}_{4}$. It implies that the interaction between $\mathrm{C}_{3} \mathrm{H}_{8}$ and $\mathrm{Ni}(\mathrm{TMBDC})(\mathrm{DABCO})_{0.5}$ is the strongest, that of $\mathrm{C}_{2} \mathrm{H}_{6}$ is in the second place, and that of $\mathrm{CH}_{4}$ is the weakest, which is mainly determined by the property of $\mathrm{CH}_{4}, \mathrm{C}_{2} \mathrm{H}_{6}$ and $\mathrm{C}_{3} \mathrm{H}_{8}$, especially molecule polarizabilities. The polarizability is considered as an important intrinsic property of a molecule that reflects the ability to generate instantaneous dipole related to Van der Waals interactions within the molecule, which dominate the interactions between the molecule and an adsorbent. ${ }^{[32,40]}$ The polarizabilities of $\mathrm{C}_{3} \mathrm{H}_{8}, \mathrm{C}_{2} \mathrm{H}_{6}$ and $\mathrm{CH}_{4}$ are $62.9-63.7 \times 10^{25}, 44.3-44.7 \times 10^{25}, 25.93 \times 10^{25} \mathrm{~cm}^{-3}$, respectively. ${ }^{[16]}$ Therefore, $\mathrm{C}_{3} \mathrm{H}_{8}$ and $\mathrm{C}_{2} \mathrm{H}_{6}$ would likely exhibited stronger interaction towards the surface of $\mathrm{Ni}$ (TMBDC)(DABCO $)_{0.5}$. The strong interaction is also evidenced by the isosteric heat $\left(\mathrm{Q}_{\mathrm{st}}\right)$. As presented in Figure S5, the $\mathrm{Q}_{\mathrm{st}}$ values of $\mathrm{C}_{3} \mathrm{H}_{8}$ and $\mathrm{C}_{2} \mathrm{H}_{6}$ reached $59 \mathrm{~kJ} / \mathrm{mol}$ and $36 \mathrm{~kJ} / \mathrm{mol}$ at $0.5 \mathrm{kPa}$, respectively, while that of $\mathrm{CH}_{4}$ is $14 \mathrm{~kJ} / \mathrm{mol}$, demonstrating strong interaction of $\mathrm{C}_{3} \mathrm{H}_{8}$ and $\mathrm{C}_{2} \mathrm{H}_{6}$ within $\mathrm{Ni}(\mathrm{TMBDC})(\mathrm{DABCO})_{0.5}$. It is noticed that, at the pressure region of $15 \sim 100 \mathrm{kPa}$, the uptake of $\mathrm{C}_{3} \mathrm{H}_{8}$ is lower than $\mathrm{C}_{2} \mathrm{H}_{6}$. This should be attributed that the molecular kinetic diameter of $\mathrm{C}_{3} \mathrm{H}_{8}(4.3 \sim 5.1 \AA)$ is larger than that of $\mathrm{C}_{2} \mathrm{H}_{6}(4.4 \AA)$, thus less $\mathrm{C}_{3} \mathrm{H}_{8}$ molecules could be accommodated in the limited pore volume of $\mathrm{Ni}(\mathrm{TMBDC})(\mathrm{DABCO})_{0.5}$ compared to $\mathrm{C}_{2} \mathrm{H}_{6}$.

It is worth to mention that the $\mathrm{Ni}(\mathrm{TMBDC})(\mathrm{DABCO})_{0.5}$ adsorbed $\mathrm{C}_{3} \mathrm{H}_{8}$ with a gate opening behavior at three temperatures as shown in Figure S6. The gate-opening pressure $\left(P_{g o}\right)$ for $\mathrm{C}_{3} \mathrm{H}_{8}$ decreased from $68 \mathrm{kPa}$ at $308 \mathrm{~K}$ to $23 \mathrm{kPa}$ at $288 \mathrm{~K}$. Such breathing behavior on hydrocarbon adsorption were observed on ELM-11, ${ }^{[33]} \mathrm{Cu}(\mathrm{dhbc})_{2}(4,4$ '-bipy $),{ }^{[34]}{ }^{34 T A}-300,{ }^{[23]}$ ZIF-7 ${ }^{[35]}$, etc. The gate-opening behavior of $\mathrm{Ni}(\mathrm{TMBDC})(\mathrm{DABCO})_{0.5}$ is considered to be induced by the adsorption of $\mathrm{C}_{3} \mathrm{H}_{8}$ molecule. ${ }^{[34]}$ The framework of the material had strong interaction with the adsorbed $\mathrm{C}_{3} \mathrm{H}_{8}$ molecule due to the methyl group and me- 
thylene group in the channel, leading to a structural transition after the first saturated adsorption capacity of $\mathrm{C}_{3} \mathrm{H}_{8}$ was obtained. As the temperature decreased, the thermal motion of $\mathrm{C}_{3} \mathrm{H}_{8}$ molecule slowed down so that the $\mathrm{C}_{3} \mathrm{H}_{8}$ molecule could be adsorbed more easily on the $\mathrm{Ni}(\mathrm{TMBDC})(\mathrm{DABCO})_{0.5}$, thereby leading to lower gate-opening pressure $\left(P_{g_{o}}\right) \cdot{ }^{[34]}$

Particularly, since the concentrations of ethane and propane are relatively low in natural gas, the adsorption ability of ethane and propane at low pressure region $(0 \sim 20 \mathrm{kPa})$ is basically important for the separation performance of $\mathrm{C} 1 / \mathrm{C} 2 / \mathrm{C} 3$. For comparison, Table 1 summarizes the low-pressure adsorption capacity of some materials for $\mathrm{C}_{2} \mathrm{H}_{6}$ and $\mathrm{C}_{3} \mathrm{H}_{8}$. It is clearly visible that the $\mathrm{C} 3$ and $\mathrm{C} 2$ uptakes in $\mathrm{Ni}(\mathrm{TMBDC})(\mathrm{DABCO})_{0.5}$ at low pressure region are comparable with those of MgMOF-74 and 0.3Gly@HKUST-1, and higher than other reported materials, such as $\mathrm{MOFs}$ and porous carbon materials, indicating a great potential of $\mathrm{Ni}(\mathrm{TMBDC})(\mathrm{DABCO})_{0.5}$ for separating $\mathrm{C} 1 / \mathrm{C} 2 / \mathrm{C} 3$.

Table 1 Comparison of $\mathrm{C}_{2} \mathrm{H}_{6} / \mathrm{C}_{3} \mathrm{H}_{8}$ adsorption capacity and $\mathrm{C}_{2} \mathrm{H}_{6} / \mathrm{CH}_{4}$ and $\mathrm{C}_{3} \mathrm{H}_{8} / \mathrm{CH}_{4}$ selectivities of some reported materials

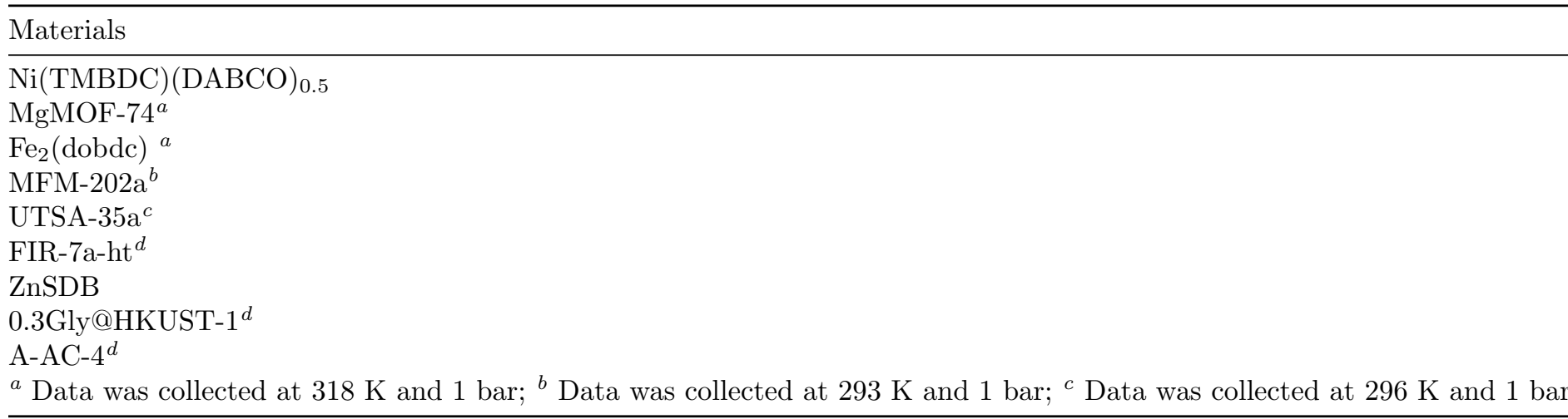

The ideal adsorbed solution theory model (IAST) was applied to predict the selectivity of binary mixtures of $\mathrm{C}_{2} \mathrm{H}_{6} / \mathrm{CH}_{4}$ and $\mathrm{C}_{3} \mathrm{H}_{8} / \mathrm{CH}_{4}$ on $\mathrm{Ni}(\mathrm{TMBDC})(\mathrm{DABCO})_{0.5}$, respectively. Firstly, dual-site LangmuirFreundlich (DSLF) model was used to fit the single component adsorption isotherms of $\mathrm{CH}_{4} / \mathrm{C}_{2} \mathrm{H}_{6} / \mathrm{C}_{3} \mathrm{H}_{8}$ at 298 K. ${ }^{[33]}$ The fitting parameters and correlation coefficients $R^{2}$ from DSLF model are listed in Table S2. The $R^{2}$ of the fitting curves for $\mathrm{CH}_{4}, \mathrm{C}_{2} \mathrm{H}_{6}$ and $\mathrm{C}_{3} \mathrm{H}_{8}$ adsorption isotherms are up to 0.999 , indicating the well description of the $\mathrm{CH}_{4}, \mathrm{C}_{2} \mathrm{H}_{6}$ and $\mathrm{C}_{3} \mathrm{H}_{8}$ adsorption behaviors on $\mathrm{Ni}$ (TMBDC)(DABCO) 0.5 by DSLF model.

(a)

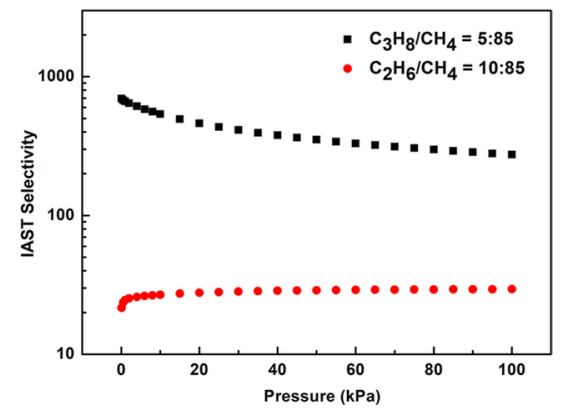

(b)

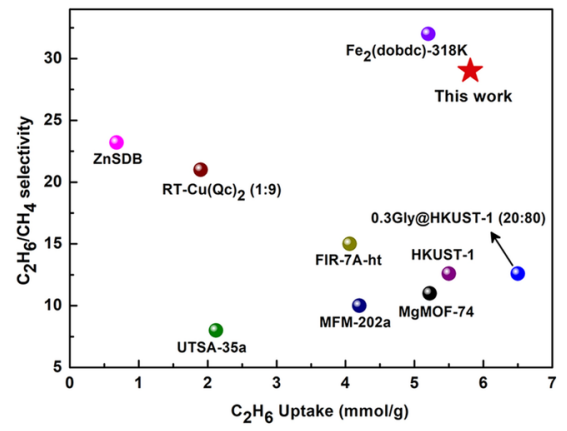

Figure 4 (a) IAST selectivity of $\mathrm{C}_{2} \mathrm{H}_{6} / \mathrm{CH}_{4}(10: 85, \mathrm{v} / \mathrm{v})$ and $/ \mathrm{C}_{3} \mathrm{H}_{8} / \mathrm{CH}_{4}(5: 85, \mathrm{v} / \mathrm{v})$ binary mixtures on $\mathrm{Ni}(\mathrm{TMBDC})(\mathrm{DABCO})_{0.5}$ at $298 \mathrm{~K}$; (b) Comparison of selectivity for $\mathrm{Ni}(\mathrm{TMBDC})(\mathrm{DABCO})_{0.5}$ and other 
reported MOFs

Figure 4(a) shows the IAST selectivities of Ni(TMBDC) (DABCO) 0.5 at $298 \mathrm{~K}$ for the $\mathrm{C}_{2} \mathrm{H}_{6} / \mathrm{CH}_{4}(10: 85, \mathrm{v} / \mathrm{v})$ and $\mathrm{C}_{3} \mathrm{H}_{8} / \mathrm{CH}_{4}(85: 5, \mathrm{v} / \mathrm{v})$ binary mixtures. The $\mathrm{C}_{2} \mathrm{H}_{6} / \mathrm{CH}_{4}$ selectivity reached as high as 29 at $298 \mathrm{~K}$ and $100 \mathrm{kPa}$, and its $\mathrm{C}_{3} \mathrm{H}_{8} / \mathrm{CH}_{4}$ selectivity exhibited a descending trend in the range of $0 \sim 100 \mathrm{kPa}$ and reached as high as 274, which are higher than most of the materials reported to date, as shown in Table 1 . Moreover, Figure 4(b) summarizes $\mathrm{C}_{2} \mathrm{H}_{6} / \mathrm{CH}_{4}$ selectivities of $\mathrm{Ni}(\mathrm{TMBDC})(\mathrm{DABCO})_{0.5}$ and other MOFs materials. It is shown that $\mathrm{Ni}(\mathrm{TMBDC})(\mathrm{DABCO})_{0.5}$ exhibits not only high $\mathrm{C}_{2} \mathrm{H}_{6}$ capacity but also $\mathrm{C}_{2} \mathrm{H}_{6} / \mathrm{CH}_{4}$ selectivity compared to other MOFs, which could potentially address the trade-off between adsorption capacity and selectivity.

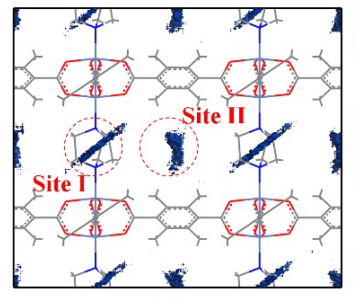

(a)

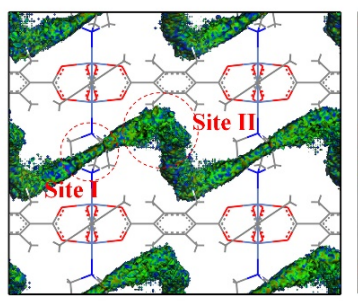

(b)

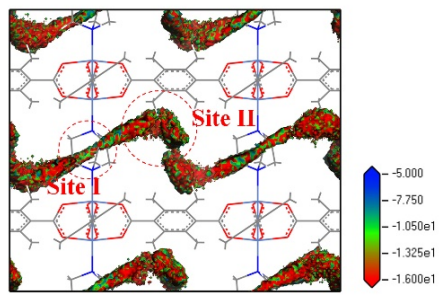

(c)

Figure 5 Simulated adsorption density distribution colored by adsorption potential of (a) $\mathrm{CH}_{4},(\mathrm{~b}) \mathrm{C}_{2} \mathrm{H}_{6}$ and $(\mathrm{c}) \mathrm{C}_{3} \mathrm{H}_{8}$ in $\mathrm{Ni}(\mathrm{TMBDC})(\mathrm{DABCO})_{0.5}$ at $1 \mathrm{kPa}$

To further understand the adsorption mechanism of $\mathrm{CH}_{4}, \mathrm{C}_{2} \mathrm{H}_{6}$ and $\mathrm{C}_{3} \mathrm{H}_{8}$ in $\mathrm{Ni}(\mathrm{TMBDC})(\mathrm{DABCO})_{0.5}$, the GCMC was applied to examine the adsorption density distribution of the three gases in the adsorbent. As illustrated in Figure 5, the $\mathrm{CH}_{4}, \mathrm{C}_{2} \mathrm{H}_{6}$ and $\mathrm{C}_{3} \mathrm{H}_{8}$ were adsorbed on two sites in the framework of $\mathrm{Ni}(\mathrm{TMBDC})(\mathrm{DABCO})_{0.5}$, which are termed as Site I and Site II. The gases adsorbed on Site I was mainly influenced by the methylene group from DABCO pillar, while those adsorbed on Site II was affected synergistically by the methyl group from TMBDC ligand and the methylene group from the adjacent DABCO pillar. That is to say, strong interaction was formed on $\mathrm{CH}_{4}, \mathrm{C}_{2} \mathrm{H}_{6}$ and $\mathrm{C}_{3} \mathrm{H}_{8}$ molecule owing to the presence of methyl and methylene group, and thus these hydrocarbon molecules were more preferentially adsorbed on the Site II and Site I.

In addition, it shows that the adsorption potentials of these alkanes in the $\mathrm{Ni}(\mathrm{TMBDC})(\mathrm{DABCO})_{0.5}$ follow the order: $\mathrm{C}_{3} \mathrm{H}_{8}>\mathrm{C}_{2} \mathrm{H}_{6}>\mathrm{CH}_{4}$, which is consistent with the order of the adsorption capacity at low pressure region. This phenomenon further confirmed that the framework of Ni(TMBDC)(DABCO) 0.5 showed stronger affinity toward $\mathrm{C}_{3} \mathrm{H}_{8}$ than $\mathrm{C}_{2} \mathrm{H}_{6}$ and $\mathrm{CH}_{4}$, which was attributed to the existence of both methyl groups and methylene groups in the channel.

Figure 6 Breakthrough curves of $\mathrm{CH}_{4} / \mathrm{C}_{2} \mathrm{H}_{6} / \mathrm{C}_{3} \mathrm{H}_{8}(85: 10: 5, \quad \mathrm{v} / \mathrm{v} / \mathrm{v})$ ternary mixtures through $\mathrm{Ni}(\mathrm{TMBDC})(\mathrm{DABCO})_{0.5}$ packed column

To evaluate the dynamic separation performance of the sample for $\mathrm{CH}_{4} / \mathrm{C}_{2} \mathrm{H}_{6} / \mathrm{C}_{3} \mathrm{H}_{8}$ mixture, breakthrough experiments at $298 \mathrm{~K}$ were performed, in which the stimulated industrial gas mixture of $\mathrm{CH}_{4} / \mathrm{C}_{2} \mathrm{H}_{6} / \mathrm{C}_{3} \mathrm{H}_{8}(85: 10: 5, \mathrm{v} / \mathrm{v} / \mathrm{v})$ was applied. Figure 6 presents the breakthrough curves of ternary mixtures $\mathrm{CH}_{4} / \mathrm{C}_{2} \mathrm{H}_{6} / \mathrm{C}_{3} \mathrm{H}_{8}(85: 10: 5, \mathrm{v} / \mathrm{v} / \mathrm{v})$ through the packed column with $\mathrm{Ni}(\mathrm{TMBDC})(\mathrm{DABCO})_{0.5}$. It demonstrates that these three gases were completely separated with the breakthrough time of 80 min for $\mathrm{C}_{3} \mathrm{H}_{8}, 24 \mathrm{~min}$ for $\mathrm{C}_{2} \mathrm{H}_{6}$, and $4 \mathrm{~min}$ for $\mathrm{CH}_{4}$. In addition, the recyclability of $\mathrm{Ni}(\mathrm{TMBDC})(\mathrm{DABCO})_{0.5}$ was also examined. Figure S7 presents the breakthrough curves of three adsorption-desorption cycles on $\mathrm{Ni}(\mathrm{TMBDC})(\mathrm{DABCO})_{0.5}$. It shows that the breakthrough curves of these ternary mixtures almost overlap, indicating excellent recycling performance of $\mathrm{Ni}(\mathrm{TMBDC})(\mathrm{DABCO})_{0.5}$. These great separation property 
and recyclability of the $\mathrm{Ni}(\mathrm{TMBDC})(\mathrm{DABCO})_{0.5}$ would make it a great candidate for challenging separation of $\mathrm{CH}_{4} / \mathrm{C}_{2} \mathrm{H}_{6} / \mathrm{C}_{3} \mathrm{H}_{8}$ mixture or recovering low content of $\mathrm{C}_{2} \mathrm{H}_{6}$ and $\mathrm{C}_{3} \mathrm{H}_{8}$ from natural gas.

\section{Conclusion}

In summary, we synthesized a microporous metal-organic framework, $\mathrm{Ni}(\mathrm{TMBDC})(\mathrm{DABCO})_{0.5}$ and investigated its separation performance for recovery low content of $\mathrm{C}_{2} \mathrm{H}_{6}$ and $\mathrm{C}_{3} \mathrm{H}_{8}$ from natural gas. The as-synthesized Ni(TMBDC)(DABCO) $)_{0.5}$ showed good thermal stability, solvent stability and humid stability under $\mathrm{RH}=100 \%$. Due to the strong interaction between the framework and the guest molecule, the gate opening behavior of $\mathrm{C}_{3} \mathrm{H}_{8}$ adsorption on the $\mathrm{Ni}(\mathrm{TMBDC})(\mathrm{DABCO})_{0.5}$ was observed and the remarkably high capacities of $2.80 \mathrm{mmol} / \mathrm{g}$ at $1 \mathrm{kPa}$ and $3.37 \mathrm{mmol} / \mathrm{g}$ at $5 \mathrm{kPa}$ were obtained. The IAST-predicted selectivity of $\mathrm{Ni}(\mathrm{TMBDC})(\mathrm{DABCO})_{0.5}$ reached as high as 274 for $\mathrm{C}_{3} \mathrm{H}_{8} / \mathrm{CH}_{4}(5: 85, \mathrm{v} / \mathrm{v})$ and 29 for $\mathrm{C}_{2} \mathrm{H}_{6} / \mathrm{CH}_{4}$ (10:85). The breakthrough experiment revealed that simulated gas mixture of $\mathrm{C} 1 / \mathrm{C} 2 / \mathrm{C} 3$ was well separated on the $\mathrm{Ni}(\mathrm{TMBDC})(\mathrm{DABCO})_{0.5}$ material. The molecular simulation further confirmed the methylene groups and methyl groups played a crucial role on $\mathrm{C}_{3} \mathrm{H}_{8}$ and $\mathrm{C}_{2} \mathrm{H}_{6}$ adsorption. This work unveils that the $\mathrm{Ni}(\mathrm{TMBDC})(\mathrm{DABCO})_{0.5}$ with good stability and unique pore environment is a promising material for recovering ethane and propane from natural gas or other hydrocarbon separation. Looking ahead, the shaping of $\mathrm{Ni}(\mathrm{TMBDC})(\mathrm{DABCO})_{0.5}$, for example, from powder to spherical adsorbents with excellent mechanical strength, is undergoing in our group, which is necessary before practical applications.

\section{Acknowledgements}

The authors gratefully acknowledge the National Natural Science Foundation of China (No. 21436005, No. 21978099), the Research Foundation of State Key Lab of Subtropical Building Science of China (2018ZC08) and the Guangdong Province Science and Technology Project (No. 2016A020221006) for the support of this work.

\section{References}

[1] D. S. Sholl, R. P. Lively. Seven chemical separations to change the world. Nature ., 2016, 532 , 435-437.

[2] J. Shen, A. Dailly, M. Beckner. Natural gas sorption evaluation on microporous materials. Micropor. Mesopor. Mat ., 2016,235, 170-177.

[3] S. Mater, L. F. Hatch. Chemistry of Petrochemical Processes 2nd edition; Gulf Publishing Company: 2001

[4] R. B. Eldridge. Olefin/paraffin separation technology: a review,Ind. Eng. Chem. Res ., 1993, 32, 2208-2212.

[5] T. Ren, M. Patel, K. Blok. Olefins from conventional and heavy feedstocks: Energy use in steam cracking and alternative processes.Energy ., 2006, 31 (4), 425-451.

[6] D. M. Ruthven, Principles of adsorption and adsorption process. John Wiley \$ Sons: 1984

[7] R. T. Yang, Adsorbents: fundamentals and applications. John Wiley \& Sons: 2003

[8] S. Hosseinpour, S. Fatemi, Y. Mortazavi, et al. Performance of CaX zeolite for separation of $\mathrm{C}_{2} \mathrm{H}_{6}$, $\mathrm{C}_{2} \mathrm{H}_{4}$, and $\mathrm{CH}_{4}$ by adsorption process; Capacity, selectivity, and dynamic adsorption measurements. Sep. Sci. Technol ., 2010, 46 , 349-355.

[9] A.M. Avila, F. Yang, M. Shi, S.M. Kuznicki. Extraction of ethane from natural gas at high pressure by adsorption on Na-ETS-10.Chem. Eng. Sci ., 2011, 66 , 2991-2996.

[10] B. Li, Y. Cui, W. Zhou, G Qian, B. Chen. Emerging multifunctional metal-organic framework materials. Adv. Mater. , 2016, $28,8819-8860$

[11] J. Y. Lee, O. K. Farha, J. Roberts, S. T. Nguyen, J. T. Hupp. Metal-organic frameworks as catalysts. Chem. Soc. Rev. , 2009,38, 1450-1459 
[12] H. Furukawa, K. E. Cordova, M. O'Keeffe, O. M. Yaghi. The chemistry and applications of metal-organic frameworks. Science. , 2013, 341, 1230444-(1-12)

[13] Z. Hu, B. J. Deibert, J. Li. Luminescent metal-organic frameworks for chemical sensing and explosive detection. Chem. Soc. Rev. , 2014, 43 , 5815-5840

[14] L. E. Kreno, K. Leong, O. K. Farha, J. T. Hupp. Metal-organic framework materials as chemical sensors. Chem. Rev. , 2012,112,1105-1125

[15] N. L. Rosi, J. Eckert, M. Eddaoudi, M. O'Keeffe, O. M. Yaghi. Hydrogen storage in microporous metal-organic frameworks.Science ., 2003, 300 , 1127-1129

[16] J. -R. Li, R. J. Kuppler, H. -C. Zhou. Selective gas adsorption and separation in metal-organic frameworks. Chem. Soc. Rev. , 2009, 38, 1477-1504

[17] R. - B. Lin, S. Xiang, H. Xing, W. Zhou, B. Chen. Exploration of porous metal-organic frameworks for gas separation and purification.Coord. Chem. Rev. , 2019, 378, 87-103

[18] Z. Zhou, C. Ma, J. Xiao, Q. Xia, Z. Li. A novel bimetallic MIL-101(Cr, Mg) with high $\mathrm{CO}_{2}$ adsorption capacity and $\mathrm{CO}_{2} / \mathrm{N}_{2}$ selectivity. Chem. Eng. Sci. , 2016, 147, 109-117

[19] Z. Zhang, Z. -Z. Yao, S. Xiang, B, Chen. Perspective of microporous metal-organic frameworks for $\mathrm{CO}_{2}$ capture and separation. Energy. Environ. Sci. , 2014, 7, 2868-2899

[20] W. Huang, X. Zhou, Q. Xia, J. Peng, H. Wang, Z. Li. Preparation and adsorption performance of GrO@Cu-BTC for separation of $\mathrm{CO}_{2} / \mathrm{CH}_{4}$. Ind. Eng. Chem. Res. , 2014, 53, 11176-11184

[21] M. K. Taylor, T. Runčevski, J. Oktawiec, J. E. Bachman, J. R. Long. Near-perfect $\mathrm{CO}_{2} / \mathrm{CH}_{4}$ selectivity achieved through reversible guest templating in the flexible metal-organic framework Co(bdp). J. Am. Chem. Soc. , 2018,140, 10324-10331

[22] Y. Ye, Z. Ma, R. -B. Lin, R. Krishna, W. Zhou, B. Chen. Pore Space partition within a metal-organic framework for highly efficient $\mathrm{C}_{2} \mathrm{H}_{2} / \mathrm{CO}_{2}$ separation.J. Am. Chem. Soc. , 2019, 141, 4130-4136

[23] R. -B. Lin, L. Li, H. Wu, H. Arman, B. Li, W. Zhou, B. Chen. Optimized separation of acetylene from carbon dioxide and ethylene in a microporous material. J. Am. Chem. Soc. , 2017, 139, 8022-8028

[24] P. -Q. Liao, W. -X. Zhang, J. -P. Zhang, X. -M. Chen. Efficient purification of ethene by an ethanetrapping metal-organic framework.Nat. Commun., 2015, 6 , 8697-8705[25] W. Liang, F. Xu, X. Zhou, J. Xiao, Z. Li. Ethane selective adsorbent $\mathrm{Ni}(\mathrm{bdc})(\text { ted })_{0.5}$ with high uptake and its significance in adsorption separation of ethane and ethylene. Chem. Eng. Sci. , 2016, 148, 275-281

[26] Y. Wu, Y. Sun, J. Xiao, X. Wang, Zhong Li. Glycine-modified HKUST-1 with simultaneously enhanced moisture stability and improved adsorption for light hydrocarbons separation. ACS Sustainable Chem. Eng. , 2019, $7,1557-1563$

[27] S. Gao, C. G. Morris, Z. Lu, Y .Yan, K. M. Thomas, S. Yang, M. Schroder. Selective hysteretic sorption of light hydrocarbons in a flexible metal-organic framework material. Chem. Mater. , 2016,28 , 2331-2340

[28] Y. He, R. Krishna, B. Chen. Metal-organic frameworks with potential for energy-efficient adsorptive separation of light hydrocarbons. Energy Environ. Sci. , 2012, 5 , 9107-9120

[29] E. D. Bloch, W. L. Queen, R. Krishna, J. M. Zadrozny, C. M. Brown, J. R. Long. Hydrocarbon separations in a metal-organic framework with open iron(II) coordination sites. Science. , 2012,335, $1606-1610$

[30] X. Wang, Z. Niu, A. M. Al-Enizi, L. Wojtas, Y. -S. Chen, Z. Li, S. Ma. Pore environment engineering in metal-organic frameworks for efficient ethane/ethylene separation. J. Mater. Chem. A., 2019,7, 1358513590 
[31] A. Hijazi, S. Floquet, J. Marrot, J. Fize, V. Artero. Tuning the electrocatalytic hydrogen evolution reaction promoted by $\left[\mathrm{Mo}_{2} \mathrm{O}_{2} \mathrm{~S}_{2}\right]^{-}$based molybdenum cycles in aqueous medium. Dalton Trans. , 2013,42, $4848-4858$

[32] W. Liang, H. Xiao, D. Lv, J. Xiao, Z. Li. Novel asphalt-based carbon adsorbents with super-high adsorption capacity and excellent selectivity for separation for light hydrocarbons. Sep. Purif. Technol. , 2018, $190,60-67$

[33] L. Li, R. Krishna, Y. Wang, X. Wang, J. Yang, J. Li. Flexible metal-organic frameworks with discriminatory gate opening effect for the separation of acetylene from ethylene/acetylene mixtures. Eur. J. Inorg. Chem. , 2016 , 4457-4462

[34] Li L., Krishna R., Wang Y., J. Li. Exploiting the gate opening effect in a flexible MOF for selective adsorption of propyne from C1/C2/C3 hydrocarbons. Journal of Materials Chemistry A . 2016,4 (3), 751755.

[35] C. Gücüyener, J. Bergh, J. Gascon, F. Kapteijn, Ethane/ethene separation turned on its Head: selective ethane adsorption on the metal-organic framework ZIF-7 through a gate-opening mechanism. J. Am. Chem. Soc. , 2010, 132, 17704-17706

[36] Y. He, Z. Zhang, S. Xiang, B. Chen. A robust doubly interpenetrated metal-organic framework constructed from a novel aromatic tricarboxylate for highly selective separation of small hydrocarbons. Chem. Commun ., 2012, 48, 6493-6495.

[37] He Y. P., Tan Y. X., Zhang J. Tuning a layer to a pillared-layer metal-organic framework for adsorption and separation of light hydrocarbons. Chem. Commun ., 2013, 49 , 11323-11325.

[38] F. -S. Tang, R. -B. Lin, R. -G. Lin, B. Chen. Separation of C2 hydrocarbons from methane in a microporous metal-organic framework.J. Solid. State. Chem ., 2018, 258 , 346-350.

[40] S. Du, Y. Wu, X. Wang, Q. Xia, J. Xiao, Z. Li. Facile synthesis of ultramicroporous carbon adsorbents with ultrahigh CH4 uptake by in situ ionic activation. AIChE J. 2020; e16231. 